\title{
Caricature in Palestinian very Short Stories Written by Diasporic Writers
}

\author{
Samah Safouri Khoury \\ Arabic language and literature Department, Oranim college \\ samahkh@gmail.com \\ https://orcid.org/0000-0002-9667-2674
}

DOI: http://doi.org/ 10.36892/ijlls.v3i4.729

\begin{tabular}{|c|c|}
\hline Received: & Abstract \\
\hline 19.10 .2021 & This article studies the caricature techniques used in Palestinian very \\
\hline $\begin{array}{l}\text { Accepted: } \\
28.10 .2021\end{array}$ & $\begin{array}{l}\text { short stories written by writers living in the diaspora. This study includes } \\
\text { three examples of very short stories in which caricature is manifested in } \\
\text { events, characters and language. This technique is used in order to try to }\end{array}$ \\
\hline $\begin{array}{l}\text { Keywords: } \\
\text { caricature, diaspora, } \\
\text { very short story, } \\
\text { Palestinian, } \\
\text { technique }\end{array}$ & $\begin{array}{l}\text { it created, and the effects it had on society, politics and economics. I } \\
\text { monitored the subjects that Palestinian authors write about in very short } \\
\text { stories, and intend to expose the varied use of caricature in its different } \\
\text { techniques. This study reveals how caricature is used in very short stories } \\
\text { to expose the inhumane conditions, worsening relationships between } \\
\text { human beings, and the way people turn to violence in an attempt to solve } \\
\text { their problems. This violence surrounds people from all sides and defines } \\
\text { their relationships, whether with other people, their leaders or their } \\
\text { enemies. }\end{array}$ \\
\hline
\end{tabular}

\section{INTRODUCTION}

Diaspora literature reflects many of the issues that are considered important in the development of Palestinian literature. Some of these issues are: revolution, national struggle and movements and their reflection on individuals in society ( $F \bar{a}$ ' ùr, 2001). It also reflects the state of loss and dispossession. Many authors express the suffering they endure, living in a country that is not their own. A country that they escaped to many years before, but that oppresses them by not allowing them to work or receive citizenship (Fā'ūr, 2001; Al-Jayyūs̄i, 1997). Palestinian intellectuals were very pessimistic after they were exiled, as they had to make a living in very hard conditions and they ended up working in Arab and foreign media institutions and in companies controlled by their colonisers (Abū Al-shabāb, 1977). Many authors charged their writings with their ideas, expectations, and principles. They expressed their feelings of estrangement and their homesickness to their ancestors' land, and their dreams to return to their homes whose keys they still carry. Some used their writing to blame others for the situation of the Palestinian people and began to speak in catchy slogans, leaning towards one side and not the other (Abū Al-shabāb, 1977).

Diaspora literature repeatedly discusses the dispossession, loss, and worry that are a result of Palestinians' inability to integrate in societies that are not their own, and the hardships of acclimatizing to conditions they unwillingly found themselves in the presence of space is very prominent in these literary works writers express their strong connection with their homeland and the stability and safety it brings them (Al-Jayyūsī, 1997). Writers explain the varying degrees of suffering and its influence on the life of every Palestinian in the diaspora. Their 
works encourage the young generation to take a stand against the crimes and heinous acts committed against the Palestinian people, including imprisoning them, limiting their freedom of movement and privileging foreigners over them ( $F \bar{a} ' \bar{u} r, 2001$; (Haddād, https://pulpit.alwatanvoice.com/content/print/365108.html). Authors took upon themselves the task of spreading philosophical and social awareness, calling upon their readers to revolt against all forms of oppression to try to change the miserable reality they live in, and to constantly search for their identity under these harsh circumstances(see: Fā' ūr, 2001).

As the resistance in Lebanon and the number of institutions belonging to the Palestinian resistance increased, writers started criticizing the political reality and the organizational conditions in Lebanon and Jordan. Writers criticized the corruption and the opulent lives of political leaders, who were conspicuously distant from a life of struggle. In addition, writers also expressed the intellectuals' fears of these leaders, as they posed a threat to their interests (Shablāq, 1996). Writers criticized the general state of mankind, depicting it as an oppressed person living in a world full of injustice, or a person lost in a horrifying world (Shablāq, 1996). Some authors sympathised with realistic socialism and expressed their views of the necessity of using literature to promote human and social struggles, and to reflect the struggle taking place among revolutionaries. They believed in the ability of writers to fathom all that is hidden and expand the consciousness of mankind ( $F \bar{a}$ ' ūr, 2001; Fīshir, 1971). These writers worked to expose the nature of social relations and shed a light on their imperfections, in order to reestablish society and push it forward (Fā ūr, 2001). Many of them criticized the imperfections in the slogans that the people hold on to, that Arab regimes use to cover up their actions (which contradict their slogans) (Fā' ūr, 2001).

All of the mentioned above is enough to formulate special techniques for Palestinian writers to express their diasporic reality and their distance from their homeland. One of the techniques used in literature to express people's bitter reality is caricature. This technique has been used since the old times in drawing, and writers have used it throughout history in order to criticize the political, social and emotional conditions that influence one's choices, with the aim of exposing what goes on in one's mind and heart of frustration and bitterness towards what limits and oppresses them.

\subsection{Purpose of the Study}

In this research, I attempt to examine the caricature technique used in very short stories written by Palestinian writers in the diaspora from three main aspects. The first aspect is caricature of events, the second is caricature of language, and the third is caricature of characters. This research is divided into two parts, the first one is theoretical in which I will expand on the caricature technique and its different kinds. The second part is a practical part that demonstrates the caricature technique used in three very short stories

\section{LITERATURE REVIEW Caricature}

It is said that caricature was born with the birth of mankind. Many paintings from previous historical times have been found on walls of caves in Italy, France, The Arabian Peninsula, Egypt, Cyprus and other countries (Hamādah, 1999). Many prehistorical paintings were found also in the Algerian desert. These paintings have a comic and ridiculing nature, or a distortion of a body part or of the whole body and many of these paintings are very sexual (Hamādah, 1999). Caricature was recognised as a form of art in the $16^{\text {th }}$ century, especially after the works of the Italian Carracci brothers (Elliott, 1966).

Religions are an old target of ridicule that was expressed with paintings and literature, gods were portrayed in a very frightening way or in a ridiculing way that exaggerated their 
characteristics either to weaken their position or to get vengeance (Hamādah, 1999, 14). Ancient Greece is rich with carvings and paintings that rely heavily on exaggeration and ridicule as many characters were depicted with humour: having the tails and heads of animals, many broken teeth, or forms similar to those of donkeys or horses, with very large genitalia (Hamādah, 1999; Snodgrass, 1996). Many paintings found in Alexandria describe comic scenes of the African pygmy people. This art spread to other places and is also found in Roman mosaics (Hamādah, 1999).

In Ancient Egypt, where paintings discussed daily life as well as mythology, humour and ridicule were also used (Hamādah, 1999). One of the oldest caricatures is 3300 years old and was discovered by archaeologists in 1930. It describes King Akhenaten with big ears, a thin neck, big mouth, thin body and a head swollen in the back (Feinberg, 1998). In ancient times, the king or the leader used to gather their warriors and talk about their opponents or enemies and ridicule and laugh at them. They used to laugh at the weakness of their enemies, and their moral and physical imperfections, they gave them funny nicknames and told jokes about them (Snodgrass, 1996). As mankind started building, carvings and paintings that laughed and ridiculed the enemies were made, and these subjects were also discussed in celebrations and festivities (Wright, 1968). Therefore "caricature is a form of art inspired by reality and describes current events, but it is not a result of current events only, and its value is not measured only with time... winning time from the day it is born adds to its meaning and depth..."

In a book by Thomas Wright, he shows the most important subject that used to interest caricature painters in Ancient Egypt. He found that they used to make fun of the bad social conditions and the contradictions in the circumstances of life. There are paintings that show men as animals, which expresses the regression of the status of men in society. There are paintings that ridicule leaders and show them in an undermining way: instead of showing respect and fear, caricatures show the opposite, the king is given the same status as a servant or even lower, and is shown as defeated, weak or even stupid (Wright, 1968). Many paintings eliminate the distance between the king and his subjects, placing them closer together. Sometimes the king is a servant and the servant is a king and the people take the matters into their hands (Hamādah, 1999; Snodgrass, 1996).

The most common element in paintings of ancient cultures is ridicule, but there are differences in the ways this technique is used. Ridicule was heavily used in certain cultures and less in others. The subjects that were discussed are diverse and include different social, political and religious issues (Hamādah, 1999). The artists did not choose marginal or unimportant issues, but social problems and taboos, in order to try and rebuild the world. The first people who tried to do this were writers because they believe that caricature rearranges the chaos that is a result of protests and violence (Kernan, 1974).

Caricature in literature is considered a form of irony, the techniques used in it are the same ones used in caricature drawings and they include:

1. Simplification and Sketchiness: shedding light on certain characteristics of a person and neglecting others. These sides are considered unique for the character and therefore the reader can easily recognize the character without further effort (Smith, 1990, Gombrich, 1938). The writer tries to focus on the ugly features of a personality in order to have the funniest and most successful description (Ḥīn, 1947).

2. Nakedness is the second technique and through the writer's or painter's description, it seems that the character has no respect or dignity. There is a difference between nakedness and nudity, nudity reflects the state of a person in two positions (sports or in bed) while 


\section{Caricature in Palestinian very Short Stories Written by Diasporic Writers}

nakedness shows a position of a person that is not suitable for the context or the events, and is naked in an embarrassing situation like Adam and Eve, who knew shame after committing a sin and covered themselves with leaves (Hodgart,1969). One can see that when using the nakedness technique, writers or painters belittle the value of a person to the level of an animal (Hodgart,1969). The art of caricature relies on the magical power of the drawing, and shows the animal as the main element in the picture which marginalises humans or undermines them (Hībì , 2012).

3. The third technique is diminishing or belittling. The dimensions of certain characters are diminished in addition to their clothes, and sometimes the clothes are even gone and then the naked truth of the character is exposed and so are his or her bad deeds (Hībi , 2012). Some writers saw diminishing as reducing the organic to the mechanic, and the spiritual to the vulgar (Kernan, 1974). This reflects a reality that lacks spirituality and one's life ends up being mechanic and vulgar, empty of feeling and emotions. It becomes repulsive. In addition, reality is still and empty of anything alive (Kernan, 1974). Anything noble is made lowly, and anything important in life is brought down to the lowest level (Kernan, 1974). Writers usually use this technique to describe the smallest details, while the description of the characters is soulless, and they don't interact. The purpose of this is to express oppression and frustration (Muhammad, 2011).

4. The fourth technique is exaggeration that magnifies or enlarges characteristics of a figure's clothes or wealth or their features. This is done in order to stress the ugly characteristics and features of the character and to bring up unacceptable subjects by exaggerating their representation in order to enlighten the readers and attract them (Kernan, 1974).

5. The fifth technique is deformation in which all habits, hobbies, ideas, social statuses and main events are deformed in order to show the ugliness of the matter and how much they are controlled by satanic powers (Knust, 1975).

The aforementioned techniques show that there are many types of caricature. Christoph Martin Wieland put them in three categories:

1. True Caricature: the painter repaints the characters as $s /$ he sees them with their natural deformities(Kayser, 1963, 30).

2. Exaggerated Caricature: portrays characters while exaggerating their features and names, while giving them comic properties that make them seem vulgar but still similar to their true image (Snodgrass, 1996, 99; Elliott, 1966, 88; Kayser, 1963, 30).

3. Purely Fantastic Caricature: letting disgust, surprise, and beastly creatures take over (Kayser, 1963, 3).

\section{METHODOLOGY}

\section{Caricatures in Events}

In her story "Appetite", the Jordanian writer from Khalili origins Basma a-Nour (born in 1960) discusses the bloodshed that has become allowed in our times and uses the character of Dracula to express it.

\section{Appetite}

So much blood covered the face of the earth, but Count Dracula seems to have lost his appetite for some obscure reason. He could not have one glass, not even for the sake of being polite. Although he was still lying in his darkness among the bats, completely surrendering to 
insomnia in a beautiful coffin covered in white satin, not leading to a much yearned for death (Balhụū, 2014).

At the beginning of the story, the writer describes the huge amount of blood that was shed around the world to the level that Count Dracula, the biggest blood drinker, has decided to quit drinking blood for an obscure reason.

The obscure reason might be that his thirst is quenched and that he has had enough blood already and that he decided to stop with the habit that differentiates him from all other creatures, but he still continues to lie in his coffin in the dark with the bats because he will die if he sees the sun.

The surprising event in this story is Dracula not drinking blood anymore. He is famous for his thirst for blood and his love for murder and torture. This is a contradiction with the character of Dracula that so many stories have been told about, stories about how much he frightens people and kills them to drink their blood so he can continue living. He reached to the point where he cannot conform with the brutality of this world that has created so many Draculas around the world and others who are thirsty for blood and they shed the blood of their people and others'.

The caricaturist event reflects the character of Dracula as the victim which stresses the distorted reality of the world, as he quits his habits after seeing brutal events that have become normal in this world. Even though Dracula is known for his cruelty, the readers sympathise with him when he stops drinking blood, goes into his coffin and stays in the dark with other bats. According to this story, the world is full of bats and the sun will never shine on it again as the world has lost its way, and cruelty and oppression have become its driving forces. Dracula does not die because the darkness will not go away and the sunlight does not reach him, because this dark reality will last forever. Reality is described in an exaggerated and negative manner that has no hope and so many deformities that even Dracula himself is shocked by the amount of blood. He does not even bother to drink from it as it reaches him without any effort on his part. Dracula ceases his evil deeds after seeing that human beings have become more evil than him.

Rendering a character strange is a technique used in Dracula's character as a symbol for the people who do evil and violent acts against innocent people. In this story Dracula's character is used differently from what we already know, and the events that take place are very atypical for Dracula's stories and films. This story shows a different part of Dracula's character and the narrator uses the technique of deformation of events and social conditions in order to bring out the ugliness of the matters and the satanic control over things (Knust, 1975). The character of Dracula in this story has human characteristics (insomnia), that express Dracula's sadness about what is happening in the world and his sympathy and loss for the world and the bloodshed of the poor as a result of bad policies. Dracula will never be able to sleep, he is depicted lying in the coffin in the dark but he does not die. Thus hope is lost and there is no hope for things to get better as long as evil and humans are in the world. According to beliefs, Dracula dies when he sees sunlight or when he sees religious symbols or when holy water is thrown at him, but the narrator does not indicate that any of this will happen, so Dracula will stay in his position because people's use of religion is fake, so the world will not change for the better.

\section{Caricature in Characters}

The story "The Return to the Promised Land" by writer Liana Bader (born in 1950) speaks about returning to the Promised Land, which is the land that god has promised the Jewish people (Israel). Bader was born in Jerusalem and from there moved to Jordan and then Damascus to eventually settle in Ramallah. She describes what happens to her when she returns 
to it and the fear and horror she feels due to images that control her, she cannot get over them and feels that she is being haunted.

\section{Back to the Promised Land}

The peacock woman screamed as she entered the room, she found it overflowing with the hard wooden body of a dead cockroach that was lying on its back with its feet in the air.

As she screamed, she ran towards the mirror, she looked into the mirror and saw a man with two mustaches and honey brown eyes wrapped in a Kuffiya.

She started shaking with dear and turned around, but the body of the cockroach started swelling until it filled the room.

Her hair grew long, and every single hair on her head stood vertically.

She gasped as hair fear grew, looked for the hole of the door to unlock it with her key, but the hole in the door was shut and a rifle came out of it pointing at her (Bawārdī \& Abū Bakr \& Abū Hashhash, \& Shqīr, 2011, 112).

The story is divided into four paragraphs, each of them showing the woman's reactions to what she's imagining. At the beginning, the narrator describes the woman as a peacock. Usually, when people are described as peacocks, it is not flattering since they are seen as cocky and snobbish. This characteristic is used here to diminish the woman and belittle her to become a peacock which is considered as using the technique of nakedness for her value and making her into an animal. Afterwards, the woman is surprised to see a huge dead cockroach the size of her room. Due to its large size, the woman is still afraid of it even though it's dead. Exaggeration is used to describe the cockroach and it is described to the smallest details and its woodenness and hence tries to objectify it. Despite the fact that it's dead, the woman is horrified and runs to the mirror only to find an Arab man wrapped in a Kuffiyah in the mirror instead of the reflection of the cockroach. So the woman is the reflection of the Arab man that plants fear in her heart exactly like the cockroach in the room. The reflection of the Arab man in the mirror is used to belittle and diminish the man by comparing him to the big cockroach. The man is so diminished because he doesn't really exist in the room and he is only a reflection of the huge cockroach that has taken over the room.

The writer returns to describing the woman and stresses the first description of her as a peacock as her hair grows longer and it stand vertically which resembles the feathers of a peacock which shows her horror of what she's seeing. The writer uses a caricaturist style in this image as she mocks the woman and describes her with humor more than fear. She tries to leave the room but then she is surprised with a gun pointed at her from the hole of the door. There is a bit of an exaggeration in this last image since a rifle cannot go through the keyhole of a door. The writer uses exaggeration in describing the keyhole that is the only way for the woman to escape the room and the horrible images that she is seeing, but the rifle closes in on her, leaving her with no hope of waking up from her nightmare.

It turns out that the image of the Palestinian man in the mirror is a nightmare that chases the woman from one place to the other, threatening her existence as she imagines the cockroach as an Arab man and the keyhole becomes the muzzle of a rifle. These objects don't exist in the room but they were reflected from the woman's image in the mirror- a reflection that usually shows the truth. Therefore, the woman in this story is Jewish and her identity is discovered through the title of the story as it is the Promised Land- Israel- for Jews. As the woman returns to the Promised Land, she doesn't feel safe and feels like someone is chasing her and threatening her and it is the ghost of the Palestinian Arab that she sees as a huge cockroach that 
despite of its death and the fact that it doesn't threaten her in any way, she is still afraid and tries to escape the room that does not have more space to contain her fear and she is incapable of staying near the cockroach or the man with the Kuffiyah. She is surprised by the rifle being pointed at her as death and threats follow her.

This story is built on illusions and nightmares that the woman sees everywhere and she sees an Arab man in front of her even in a dead cockroach and in front of the mirror or the keyhole, all those three are objects (also the cockroach is an object since it's dead and still). One of the techniques of caricature is giving life to still objects that change the features and the nature of things. The same goes to comparing the woman to a peacock as it gives her features that are not human and therefore the writer marginalizes the role of the woman and belittles her and her value. On the other hand, the narrator gives value to the cockroach that becomes the size of the room, and also to the keyhole out of which comes the rifle. Despite the fact that the woman is a central character in this story, she cannot control the unfolding events, because her will and power have been taken away from her. All she can do is scream while objects control her from the beginning of the story till its end, therefore, the character of carnival has a strong presence in this story.

\section{Caricature in Language}

In the story "Qaraqosh" by the late writer Adnan Kanafani who was born in Jaffa and lived in Syria, he discusses the subject of freedom of speech and the fact that it has become impossible in the Arab world. Any person who dares to criticize policies and protest against them is either killed, imprisoned or exiled. Therefore, Arabs decided to leave the country after giving up and feeling desperate about the situation their country is in.

\section{Qaraqosh}

A strict decree from the Sultan orders:

Every donkey (no matter what kind) that brays in public spaces will be punished with impalement.

Chaos and disorder have taken over and the animals and creatures of the forest are running away from their homes...

A donkey saw a rabbit running away and asked him:

Why are you running away when the decree is only for us?

The rabbit laughed and said:

In a forest like this, we are all donkeys.

And he started running ferociously (Kanafānī, 2013).

Adnan Kanafani describes a symbolic decree by the Sultan that prevents donkeys from braying in public places and any donkey that doesn't implement this order will be tortured with impalement ('bn Mantīur, 1970, Kh.Z.Q), but all the animals decide to leave. When the donkey asks why, the rabbit replies that every animal in the forest is a donkey, then runs away.

The writer uses caricature language in presenting the subject, when the rabbit tells the donkey that all of the animals in the forest are donkeys, the rabbit puts everything in place and belittles it. The word "Himar" (donkey in Arabic) has a symbolic meaning in Arabic in addition to manifesting itself in the text. The donkey is portrayed as simple and stupid, he doesn't see any 
depth in the decree. Therefore, he is a symbol of a person who doesn't see the depth of matters and suffices in implementing orders without asking any questions. Donkeys are also passive and submissive to their owners, following them without question. In this story, we see the embodiment of the donkey who follows orders even if they are unjust and unfair. The donkey doesn't resist the order and doesn't ask others for help to stand against the injustice, and as he speaks to the rabbit, the reader understands that the donkey is not against the decree and doesn't rebel or disobey it. Moreover, the donkey doesn't ask why this decree was made specifically against donkeys which shows his level of simplicity and incapability of thinking about the other animals, while the rest of the animals understood that the word "donkey" is not intended only for actual donkeys. They worry about themselves before any decree is declared against them too. The rest of the animals also understand that whoever agrees to live in these conditions is a "donkey" which belittles all the species that agree to live under an unjust regime and decide not to stand up against it. They decide to escape because all the animals have given up on reality and don't see a reason to rebel or to express their opposition because they are afraid for their lives. The animals declare that running away is the best thing that can be done under the current circumstances and they give up their homes in order to stay alive.

Caricature language is also used in the tone of the Sultan who is human but describes his subjects as donkeys and shows disrespect towards them. He includes all of his subjects without excluding anyone and so readers can sense the way in which the Sultan looks down on his subjects. Lingual diminishing is used to show the degree to which leaders ridicule the people they rule, regardless of whether the people are educated or not, rich or poor, near or far. The writer uses the caricature technique in order to describe a mundane character and criticizes it in order to get the reader to think and challenge the existence of such leaders that treat their nations as "donkeys".

The writer chose the title "Qaraqosh" after the name of the nephew of Salah a-Din al-Ayubi who ruled Acre (Akka) for his uncle for more than thirty years. He used to issue strange decrees and therefore folk stories describe him as oppressive and also tell jokes about him and his strange decrees (Sa'd, 1990). Qaraqosh is not mentioned in the story itself, but mentioning his name in the title adds value because of his strange decrees that made his subjects laugh and cry at the same time. This is repeated time and time again around the Arab world, where there are copies of Qaraqosh who make unjust rules that the people do not protest against. Therefore the saying "rule of Qaraqosh" has become very popular among people- a saying in which they admit their weakness in front of the injustices taking place against them.

\section{RESULTS AND DISCUSSION}

This study shows that caricature is used to mock and laugh at the deteriorating social, economic and emotional conditions that people in the Arab world, and specifically Palestinians, live under. In the stories used as examples in this study, violence at the top of the list of the subjects that Palestinian writers discuss, indicating that citizens find it difficult to deal with violence and surrender, instead choosing to escape as a solution to the crisis they live in as shown in "Qaraqosh". "The Promised Land" shows how others see Palestinians and their Nakba and history and they are portrayed as monstrous and terrorist and not seen as human, rather as frightening and a nightmare to others. This is also shown in "Appetite" in which Dracula feels that human beings have exceeded his own ability to shed blood.

One of the techniques used in the stories is exaggeration. In Basma al-Nasour's story "Appetite", this is used to criticize violence and bloodshed. Layana Bader criticizes the stereotypes of Palestinian men in "The Promised Land" in which the Palestinian man is portrayed as a lifeless cockroach that although dead, still horrifies people. 
The technique of nakedness is also used to portray humans as beings who have lost their respect, by comparing them to animals or other objects. This technique is used in "Qaraqosh" by Adnan Kanafani to criticize the humiliation that people in the Arab world go through, and that people consider themselves donkeys for staying in countries that look down on them and don't appreciate them or their lives.

Purely Fantastic Caricature was used in the stories described in this study, in which writers use fantasy and unrealistic events and characters in order to criticize harsh realities. This style of caricature gives the story two dimensions (one external and the other deep or hidden). Writers have used symbolic fictional and folkloric characters like Dracula and Qaraqosh, known for their cruelty and mercilessness. It seems as though these two characters were chosen to express the injustice happening in the Arab world, and the unjust and oppressive leadership that has taken over it and rules it.

\section{REFERENCES}

Abū Al-shabāb, W. (1977) Șūrat Al-falasțīnī fì Al-qișṣa Al-falasținiyya Al-mu āṣira min sanat 1948 'ila sanat 1973. Bayrūt: dar Al-țalī'a lil-tibā’a wal-nashr.

Al-Jayyūs̄̄, S. (1997). Mawsū 'at al-'adab Al-falasțīnī Al-mu āṣir. Bayrūt: Al-Mu'assasah Al'arabiyyah Lil-Dirāsāt wa-Nashr.

Bawārdī, B. and Abū Bakr, W. and Abū Hashhash, A. and Shqīr, M. (2011) Al-qișṣah Alqașīrah Juddan. Ramallah: Markiz 'ugārīt.

'bn Manțūr, J. A. (1970) Lisān Al-'arab, Bayrūt: Dār șādir.

Elliott, Robert C. (1966). The power of Satire: Magic, Ritual, Art.New Jersey: Princeton.

Fā'ūr, Y. (2001). Al-qișșah Al-qașīrah Al-falasținiyyah Mīlāduhā Watațawwuruhā (19241990). Simashq: Manshūrāt ittiḥhād Al-kuttāb Al- 'arab.

Feinberg, Leonard. (1998). Introduction to Satire. Ames, Iowa: Iowa State Press.

Fīshir, A. (1971). Darūrat Al-fann. Al-qāhirah: Al-hay'ah Al-Mașriyyah Al-'āmmah.

Gomrich, E.H. and Ernst Kris (1938) .The Principle of Caricature. British Journal of Medical Psychology, Vol.17, pp.42-319.

Haddād, T. al-'adab Al-falasṭin̄ī wa'umquhu Al-tārīhn̄. Mawqi' dunyā al-wațan. https://pulpit.alwatanvoice.com/content/print/365108.html

Ḥamādah, M. (1999) Fann Al-kārīkâtī̄r min Judrān Al-kuhūf 'ila 'a 'midat Al-șahāâhah. Dimashq: dār 'ashtarūt Lil-țibā'ah Wal-Nashr.

Hībī, F. (2012). Al-Sukhriyya fi al-Riwāyah l-Lubnāniyya (1975-2005) (Hayfā: Maktabat kul Shay'.

Hodgart, M. (1969). Satire. London World University Library.

Ḥī̄n, M (1947). Al-hijā' qal-hajjā'ūn fì Al-jāhilyyah. Al-qāhirah: Maktabat al-'ādāb fì Aljamāmīz.

Kanafānī, '. (2013). "Al-qișșah Al-qașīrah Jiddan- 'ishkāliyyah fĩ Al-nașṣ 'am Jadaliyyah ḥawl Mușțalạ̣" Muntada Multaqa Al-'udabā' wal-mubdi '̄n Al-'arab. Al-jam 'iyyah Al'ilmiyyah Al-su'ūdiyyah.

Kayser, Wolfgang. (1963). The Grotesque in the Art and Literature. New York: Indiana University Press.

Kernan, Alvin. (1974). The Plot of Satire. London: Collins.

Knust, Herbert. (1975). "Literature and Caricature". Comparative Literature Studies. 12/3, pp.218-247.

Muḥammad, Sh. (2011). Al-Tajrīb Fī Al-qișșah Al-qașīrah Min 1960-2000. Dasūq: Al-'ilm wal-'īmān Lil-Nashr Wal-tawzī' .

Shablāq, '. (1996). Al-filisținniyūn $f \grave{l} \quad$ ūrūbā. Mawqi' Falasțīn http://palestine.assafir.com/Article.aspx?ArticleID=2309 
Smith, K. (1990). "Architectural Sketchiness and the Power of Caricature". Journal of Architectural Education, 44/1, pp.49-58.b

Snodgrass, M. (1996). Encyclopedia of Satirical Literature. California: ABC-CLIO.

Wright, Thomas. (1968). A History of Caricature and Grotesque in Literature and Art. New York: Ungar.

\section{$\underline{\text { AUTHOR'S BIO }}$}

Samah Saffuri Khoury has a Ph.D. in Arabic language and literature from Haifa University. The Ph.d dissertation deals with the distortion in the Palestinian very short story". She is a lecturer at Oranim college, and a coordinator and a teacher of Arabic Language in at MasarAlternative school. She worked as pedagogical guide, and developed several digital units in Arabic language for high schools grade. She published several articles in Arabic and English that deal with deferent issues of the Arabic literature and language. 